http://jmscr.igmpublication.org/home/ ISSN (e)-2347-176x ISSN (p) 2455-0450 crossref DOI: https://dx.doi.org/10.18535/jmscr/v7i7.164

Journal Of Medical Science And Clinical Research

$\underline{\text { Research Article }}$

\title{
A Prospective Observational Study on People Suffering with Arrhythmogenic Right Ventricular Cardiomyopathy and Treatment Outcomes with Clinical Pharmacist Interventions
}

\author{
Authors \\ Dr Kanamala Arun Chand Roby*, Ms Padadalam Lathasri , Ms. Konduru Manasa, \\ Ms. Maturu Alekhya Reddy, Shaik. Ruksana Kowsar, Dr Kudipudi Harinadha Baba \\ *Corresponding Author
}

Dr Kanamala Arun Chand Roby

Assistant Professor, Department of Pharmacy Practice, Narayana Pharmacy College- Nellore

\begin{abstract}
Arrhythmogenic right ventricular cardiomyopathy $(A R V C)$ is a primary disease of heart muscle that results in fibro fatty replacement of the right ventricle and the sub epi cardial region of the left ventricle. Patients are at high risk for ventricular tachy arrhythmias and sudden death. This is mostly seen in young adults and teenagers.

Materials and Methodology

Place of Study: The study was a prospective observational study on people suffering with Arrhythmogenic Right Ventricular cardiomyopathy and treatment outcomes with clinical pharmacist intervention', which was carried out in the 'Department of Cardiology' at Narayana Hospitals, Nellore, a 1440 bedded multidisciplinary hospital,

Results: study the maximum number of patients was 75 and the age groups of 10-80 out of which maximum were of age group 21-30 and minimum were 10-20, the male were more suffered in that maximum were un married and the educational levels of the patients were mostly primary, the hygienic conditions, surroundings and cleanliness were good.

Discussions: The patients recovered from ARVC are very less and some are died. Some are shifted to higher centers and very less recovery. For the recovery of ARVC ICD's are used, maximum regular ICD's and subcutaneous ICD's are used and total number of days stayed in the ICU are mostly 14 days for the treatment of $A R V C$.

Conclusions: Our study concluded that most of the people suffering with ARVC are of due to genetical problems and it is observed on adults and the treatment regimen is not effective and they underwent for the ICD (Implantable Cardioverter Defibrillator).

As a clinical pharmacist and physicians want to work out to find out the treatment and the cause of ARVC.

Keywords: ICD (Implantable Cardioverter Defibrillator), Arrhythmogenic right ventricular cardiomyopathy (ARVC), cardiomyopathy.
\end{abstract}

\section{Introduction}

Arrhythmogenic right ventricular cardiomyopathy (ARVC) is a primary disease of heart muscle that results in fibrofatty replacement of the right ventricle and the subepicardial region of the left ventricle. Patients are at high risk for ventricular 
tachyarrhythmias and sudden death. This is mostly seen in young adults and teenagers.

ARVC is a genetic condition which can be inherited. It is caused by a change or mutation in one or more genes .Chances of inheriting ARVC varies the person may inherit the mutation but not develop the condition. Generally cells of heart muscle are held together by proteins. But in people with ARVC these proteins do not develop properly and so cannot keep heart muscle cells together. The muscle cells becomes detached and fatty deposits build up in an attempt to repair the damage.

ARVC usually affects the right side of heart but it can affect both sides. The changes in the heart muscle occurs like the walls of the ventricle become thin and stretched. So it cannot pump blood properly to all the body parts .ARVC can also cause Abnormal heart rhythms because of the disturbances in heart normal electrical impulses as they pass through areas of damaged and scarred muscle

\section{Epidemiology}

The incidence and prevalence of ARVC remains unknown as clinically silent cases may go unrecognized. It is estimated that it affects only a few people in thousands of population. It is more commonly seen in males in their young ages and it is mostly seen in athletes. ARVC is the important cause of sudden cardiac death in young adults approximately $11 \%$ of cases in that $22 \%$ of cases among athletes. This prognosis is worst in patients with Left ventricular involvement.

\section{Pathogenesis}

Arrhythmogenic right ventricular cardiomyopathy (ARVC) is a clinically and genetically heterogeneous disorder of heart muscle that is associated with ventricular arrhythmias and risk of sudden cardiac death, particularly in the young and athletes. Mutations in five genes that encode major components of the desmosomes, namely

$>$ junction plakoglobin (JUP),

$>$ desmoplakin (DSP),
$>$ plakophilin-2(PKP2),

$>$ desmoglein-2 (DSG2) and

$>$ desmocollin-2 (DSC2), that have been identified in approximately half of the affected probands.

The structural abnormalities in ARVC results from the fatty infiltration and fibrosis of the Right ventricular myocardium. This leads to progressive Right ventricular dilation and dysfunction.

\section{Treatment}

\section{Medications}

Prescribe medications to improve heart's pumping ability, improve blood flow, lower blood pressure, slow heart rate, remove excess fluid from body or keep blood clots from forming.

Be sure to discuss possible side effects with physician before taking any of these drugs.

\section{Surgically implanted devices}

Several types of devices can be placed in the heart to improve its functioning relieve symptoms, including:

Implantable cardioverter-defibrillator (ICD) This device monitors heart rhythm and delivers electric shocks when needed to control abnormal heart rhythms. An ICD doesn't treat cardiomyopathy, but watches for and controls abnormal rhythms, a serious complication of the condition.

\section{Materials and Methodology \\ Place of Study}

The study was a prospective observational study on people suffering with Arrhythmogenic Right Ventricular cardiomyopathy and treatment outcomes with clinical pharmacist intervention', which was carried out in the 'Department of Cardiology' at Narayana Hospitals, Nellore, a 1440 bedded multidisciplinary hospital,

\section{Study Design}

The study was a prospective observational study on people suffering with Arrhythmogenic Right Ventricular Cardiomyopathy and treatment outcomes with clinical pharmacist interventions. 


\section{Study site}

The study was conducted at Cardiology units of Narayana Hospitals, Nellore.

\section{Study Population}

This study was done in 75 patients who are suffering with Arrhythmogenic right ventricular cardiomyopathy.

$>$ Study Duration: This study was conducted for 6 months

\section{Study criteria/Patient enrollment}

Patients are enrolled in the study based on inclusion and exclusion criteria;

\section{Inclusion Criteria}

- All the patients suffering with different types of symptoms regarding heart diseases.

- Patient age in between 10-80 years

- Patients of both sexes.

\section{Exclusion Criteria}

- Lack of interest to give information.

- Pediatrics.

- Whose verbal communication was poor.

- Unconsciousness patients.

\section{Study Materials}

Patient informed consent form
A specially designed Arrhythmogenic right ventricular cardiomyopathy.

\section{Study Method}

This study will be initiated after obtaining the permission from the institutional ethical committee. The patients will be enrolled in the study after taking informed consent from them. The enrollment of patients will be done on the basis of inclusion and exclusion criteria.

The data for the present study will be collected by "Patient Interview \&Chart Review Method", which is well suited to identify all the necessary and relevant baseline information, which will be collected on a specially designed patient data collection Proforma and ARVC questionnaire which includes patient demographics like age, socio-economic status, family income, educational status, high risk factors, past and present medical/medication history, lab investigation data, radiographic data, physician medication order form, nurse's medication administration record (drug chart) and any other verbal communication data.

\section{Results}

Table: 1 shows the demographic details of the patient with all the factors of age, sex, educational level, nutritional status, marital status and ethnicity.

\begin{tabular}{|c|c|c|}
\hline Demographics & No of people & Percentage (\%) \\
\hline $\begin{array}{ll}\text { Age: } & \\
& 10-20 \\
& 21-30 \\
& 31-40 \\
41-50 \\
51-60 \\
61-70 \\
71-80\end{array}$ & $\begin{array}{c}5 \\
18 \\
15 \\
12 \\
8 \\
10 \\
7\end{array}$ & $\begin{array}{c}6.66 \% \\
24.2 \% \\
20 \% \\
16 \% \\
10.66 \% \\
13.33 \% \\
9.33 \%\end{array}$ \\
\hline $\begin{array}{c}\text { Gender: } \\
\text { Male } \\
\text { Female }\end{array}$ & $\begin{array}{l}40 \\
35\end{array}$ & $\begin{array}{l}53.33 \% \\
46.66 \%\end{array}$ \\
\hline $\begin{array}{c}\text { Marital status: } \\
\text { Married } \\
\text { Unmarried }\end{array}$ & $\begin{array}{l}35 \\
40\end{array}$ & $\begin{array}{l}46.66 \% \\
53.33 \%\end{array}$ \\
\hline $\begin{array}{c}\text { Educational level: } \\
\text { Primary } \\
\text { Secondary } \\
\text { Tertiary }\end{array}$ & $\begin{array}{c}39 \\
36 \\
9\end{array}$ & $\begin{array}{l}52 \% \\
48 \% \\
12 \%\end{array}$ \\
\hline
\end{tabular}




\begin{tabular}{|c|c|c|}
\hline Hygienic conditions: & & \\
Nutritional status & 15 & $20 \%$ \\
Excellent & 47 & $62.66 \%$ \\
Good & 13 & $17.33 \%$ \\
Poor & 10 & \\
\hline Surroundings & 42 & $13.33 \%$ \\
Excellent & 23 & $56 \%$ \\
Good & & $30.66 \%$ \\
Poor & 19 & $25.33 \%$ \\
Cleanliness & 48 & $64 \%$ \\
Excellent & 8 & $10.66 \%$ \\
Good & \\
Poor &
\end{tabular}

Graphical representation of Demographic details

\section{Gender}
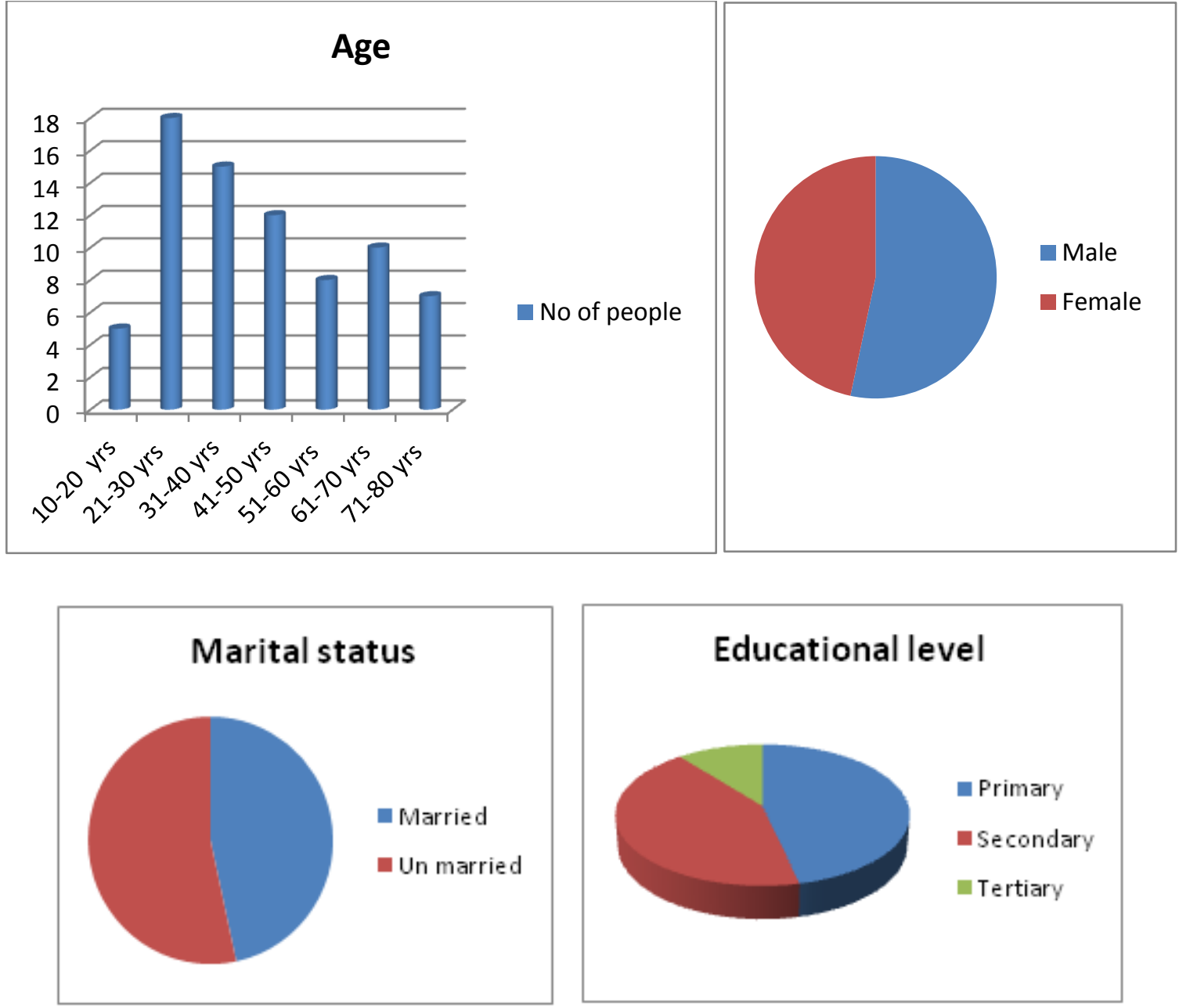

\section{Nutritional Status}

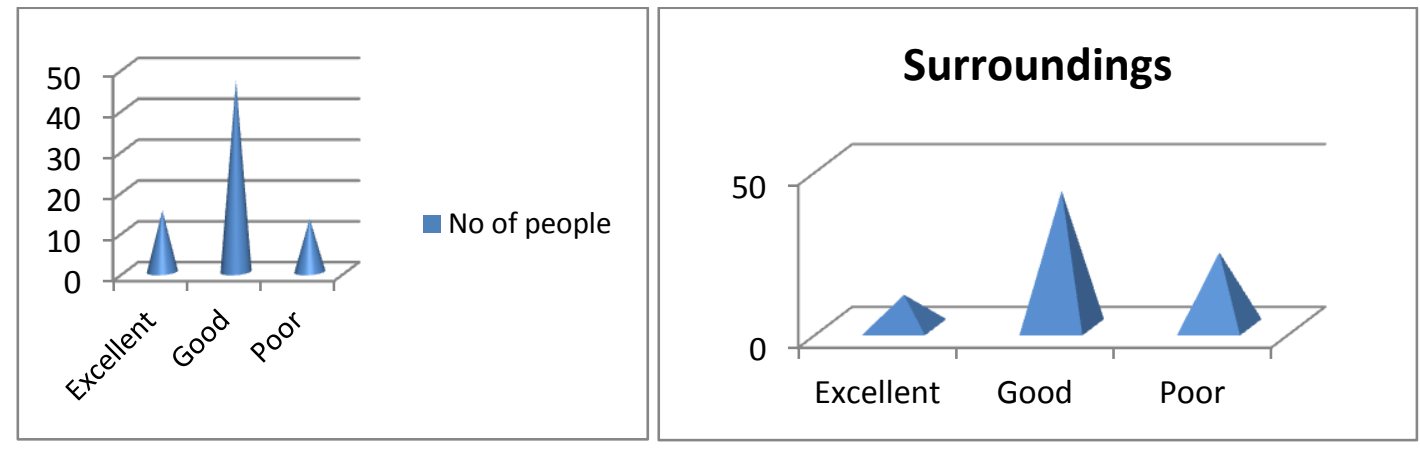




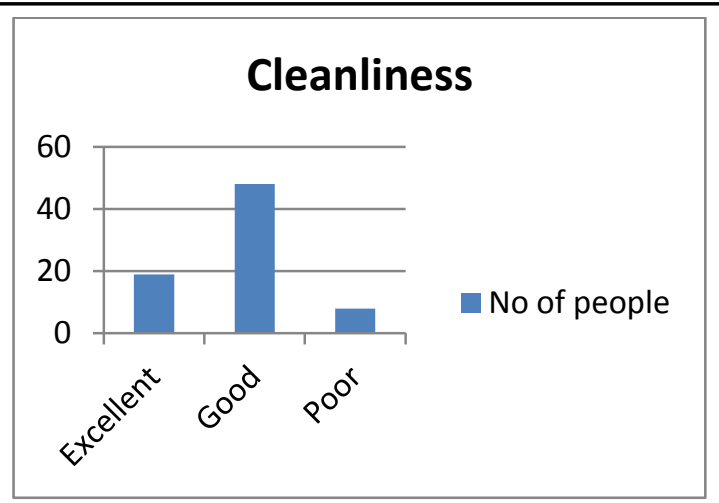

Table: 2 Reasons for admission in the hospital with number of patients and percentage

\begin{tabular}{|l|c|c|}
\hline Reason & No of patients & Frequency \\
\hline Genetic predisposition (Genes) & 26 & $34.6 \%$ \\
- JUP( Junction Plakoglobin) & & \\
- Desmoplankin(DSP) & & \\
- Plakophilin-2 (PKP2) & & \\
- Desmogilin-2 (DSG2) & & \\
Changes in the heart muscle & & \\
- Inflammation & & \\
- Enhanced fibrosis & 3 & $4 \%$ \\
- Loss of function & 7 & $9.3 \%$ \\
- Fatty replacement of myocardium & 2 & $8.66 \%$ \\
- Cell membrane damage & 5 & $6.66 \%$ \\
Atheletics due to mechanical stress & 7 & $9.3 \%$ \\
Viral infections & & \\
Coronary artery disease & 12 & $16 \%$ \\
Injury from heart attack & 2 & $2.66 \%$ \\
\end{tabular}

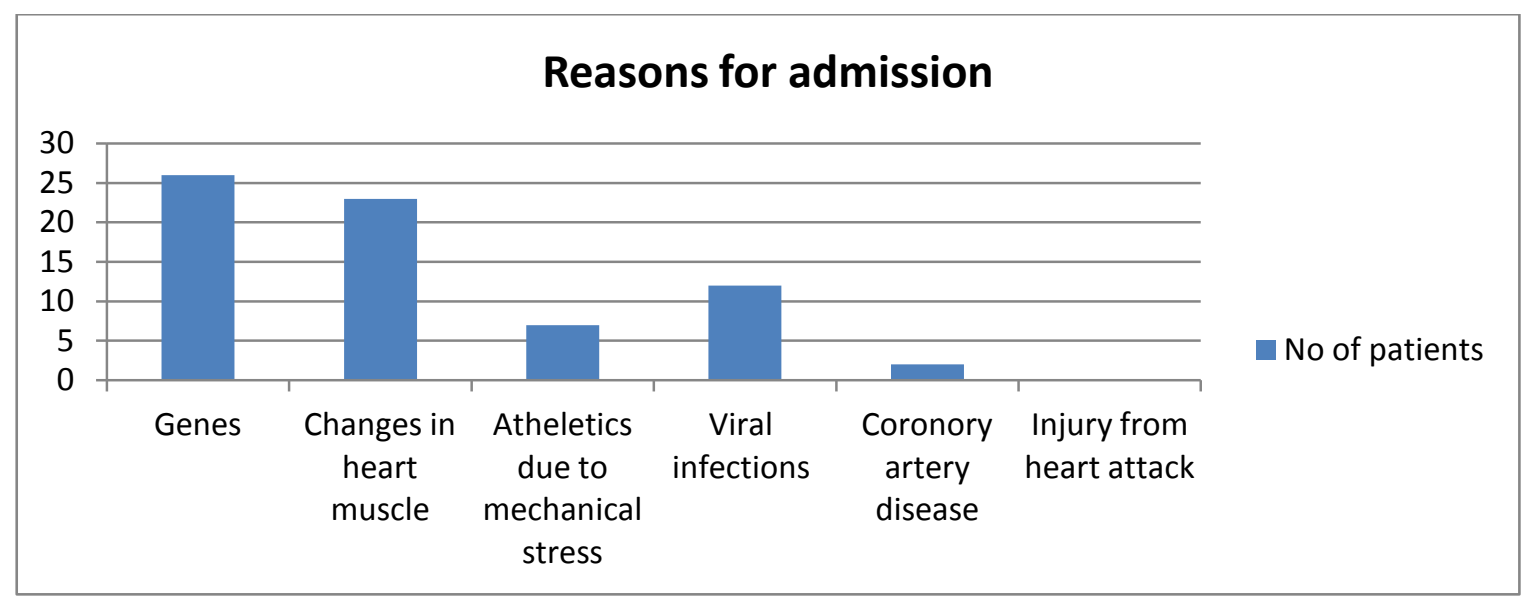

Table: 3 Symptoms

\begin{tabular}{|l|c|c|}
\hline Symptoms & No. of patients & Percentage \\
\hline Palpitations & 17 & $22.66 \%$ \\
Light headedness & 13 & $17.33 \%$ \\
Abnormal heart rhythms & 14 & $18.66 \%$ \\
Shortness of breath & 9 & $12.0 \%$ \\
Fainting & 7 & $9.33 \%$ \\
Edema & 6 & $8.0 \%$ \\
Chest pain & 9 & $12.0 \%$ \\
\hline
\end{tabular}




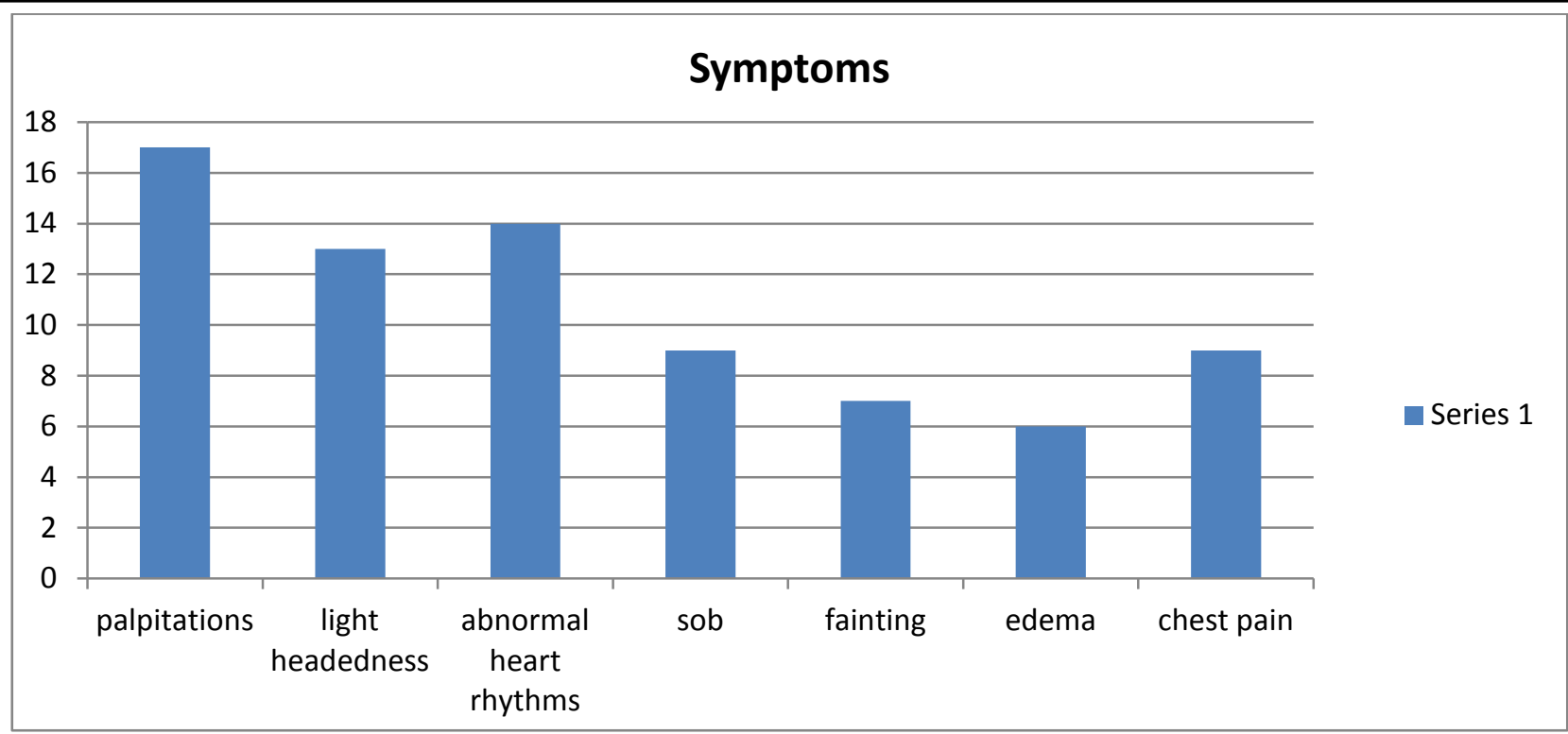

Table: 4 Shows the Treatment used for the patients with requency

\begin{tabular}{|l|c|c|}
\hline Drugs & No. of patients & Percentage \\
\hline Amiodarone & 27 & $36.0 \%$ \\
Flecainide & 4 & $5.33 \%$ \\
Procainamide & 6 & $8.0 \%$ \\
Sotalol & 23 & $30.66 \%$ \\
Metaprolol & 3 & $4.0 \%$ \\
Diltiazem & 7 & $9.33 \%$ \\
Nicardepine & 2 & $2.66 \%$ \\
Proponolol & 3 & $4.0 \%$ \\
\hline
\end{tabular}

\section{Drugs used to treat ARVC}

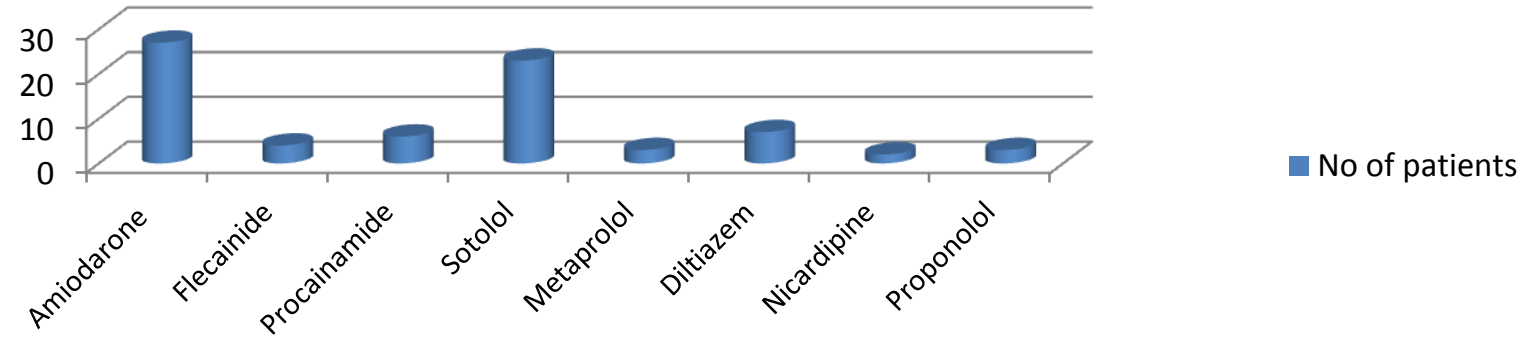

Table -5 Shows the different classes o drugs used for the disease

\begin{tabular}{|l|c|c|}
\hline Class & Drug & Dose \\
\hline Beta blokers & Proponolol & $10-80 \mathrm{mg}$ \\
& Sotolol & $40-80 \mathrm{mg}$ \\
& Metaprolol & $25-200 \mathrm{mg}$ \\
\hline Calcium channel blockers & Amliodipine & $5-10 \mathrm{mg} /$ day \\
& Diltiazem & $30-420 \mathrm{mg}$ \\
& Nicardipine & $20-40 \mathrm{mg}$ \\
\hline Potassium channel openers & Amiodarone & $400-1600 \mathrm{mg} /$ day \\
\hline Sodium channel blokers & Flecainide & $50-150 \mathrm{mg}$ \\
& Procainamide & $0.5-1.0 \mathrm{~g} / \mathrm{day}$ \\
\hline
\end{tabular}




\section{JMSCR Vol||07||Issue||07||Page 926-934||July}

Table: 6 Shows number of patients recovered from ARVC after treatment

\begin{tabular}{|l|c|c|}
\hline Recovery & No of patients & Frequency \\
\hline Recovered & 7 & $9.33 \%$ \\
No response & 33 & $44.0 \%$ \\
Died & 24 & $32.0 \%$ \\
Shifted to higher centre & 11 & $14.66 \%$ \\
\hline
\end{tabular}

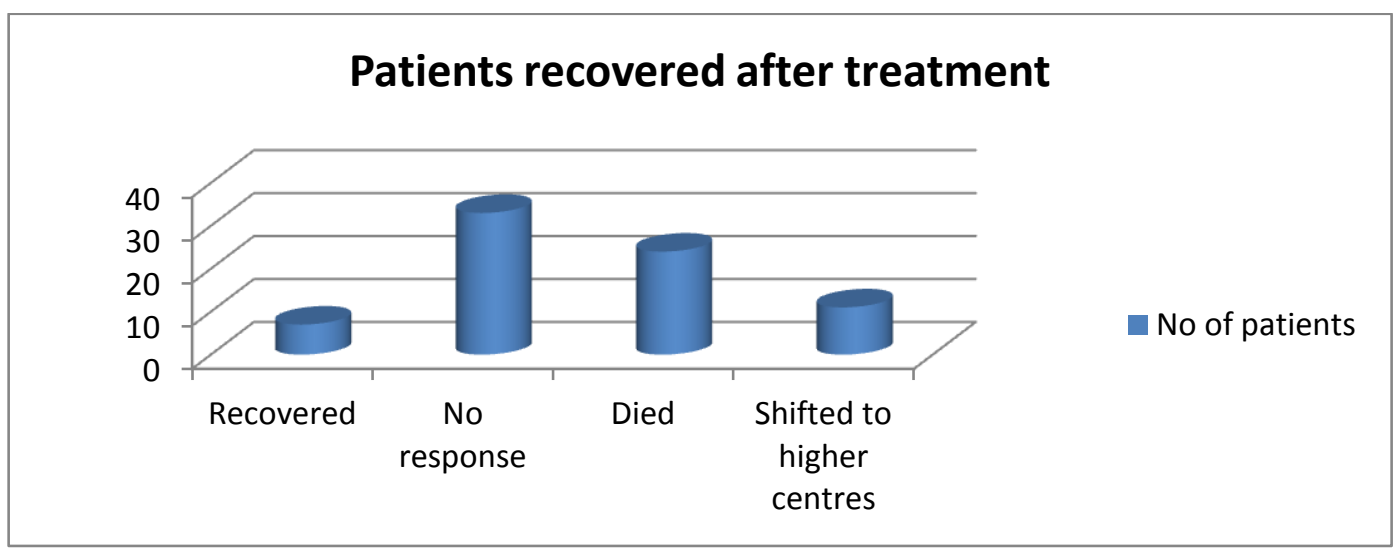

Table: 7 Shows number of patients went to ICD (Implantable Cardioverter Defibrillator)

\begin{tabular}{|l|c|c|}
\hline Types of ICD`s & No of patients & Percentage \\
\hline Regular ICD's & 45 & $60.0 \%$ \\
Subcutaneous ICD's & 30 & $40.0 \%$ \\
\hline
\end{tabular}

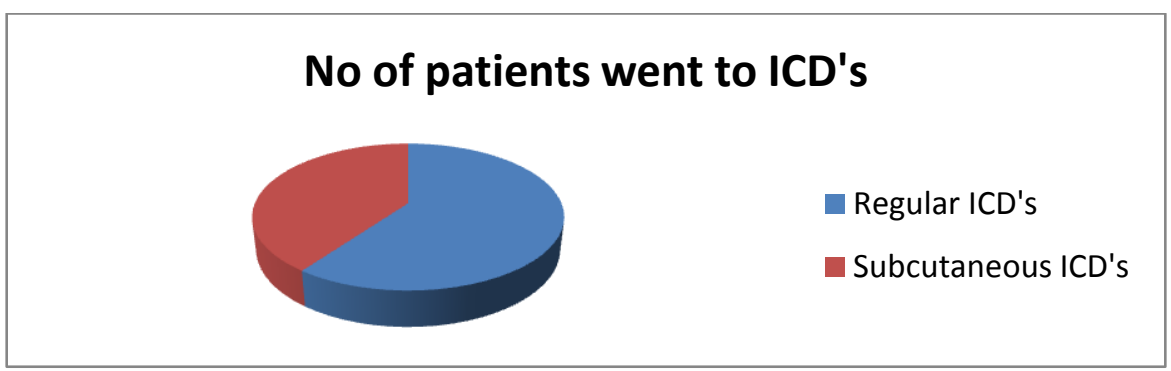

Table -8 Shows number of days stayed in ICUdue to ARVC

\begin{tabular}{|l|c|c|}
\hline Days of stay in ICU & No of patients & Percentage \\
\hline 7 days & $\mathbf{2 5}$ & $\mathbf{3 3 . 3 3 \%}$ \\
14 days & 30 & $\mathbf{4 0 . 0 \%}$ \\
21 days & 20 & $\mathbf{2 6 . 6 6 \%}$ \\
\hline
\end{tabular}

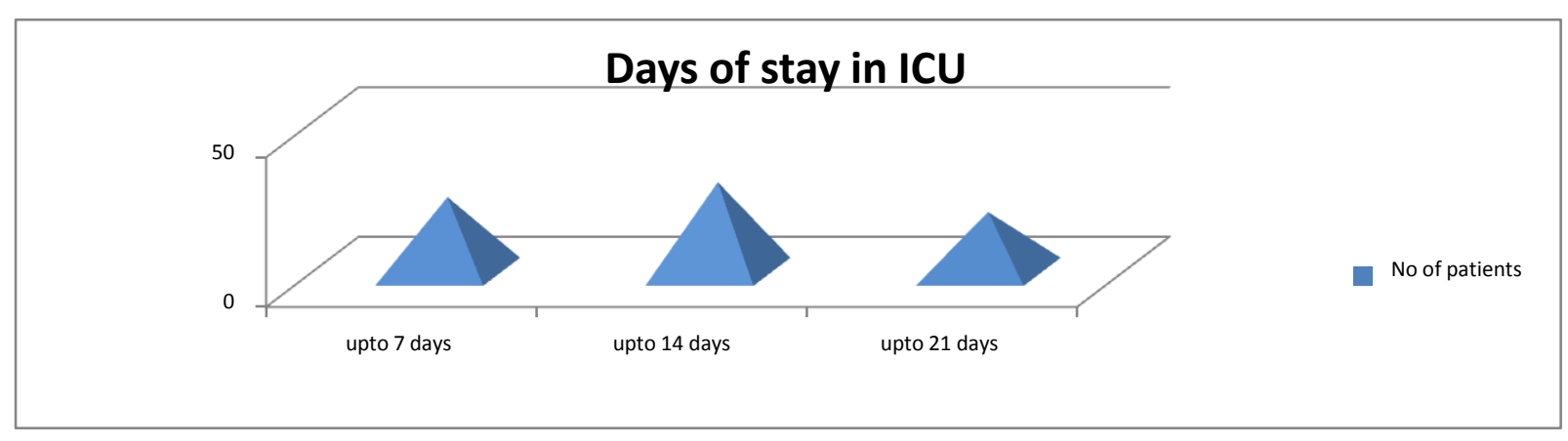

\section{Discussion}

In our study the maximum number of patients was 75 and the age groups of 10-80 out of which maximum were of age group 21-30 and minimum were 10-20, the male were more suffered in that maximum were un married and the educational 
levels of the patients were mostly primary, the hygienic conditions, surroundings and cleanliness were good. The reasons for admission in the hospital of ARVC is mostly due to Genetic predisposition is of $26(34.6 \%)$, changes in the heart muscle. Athletes due to mechanical stress, viral infections are also cause of ARVC.

The symptoms observed during admission in the hospital are mostly palpitations and the minimum were edema.

The drugs used for the treatment of ARVC is mostly Amiodarone and Sotalol and least were of Nicardipine. The class of drugs prescribed mainly are Beta blockers, Calcium channel Blockers, Potassium channel openers and Sodium channel blockers. The patients recovered from ARVC are very less and some are died. Some are shifted to higher centers and very less recovery. For the recovery of ARVC ICD's are used, maximum regular ICD's and subcutaneous ICD's are used and total number of days stayed in the ICU are mostly 14 days for the treatment of ARVC

\section{Conclusions}

Our study concluded that most of the people suffering with ARVC are of due to genetical problems and it is observed on adults and the treatment regimen is not effective and they underwent for the ICD (Implantable Cardioverter Defibrillator).

As a clinical pharmacist and physicians want to work out to find out the treatment and the cause of ARVC.

\section{Acknowledgement}

All thanks and praises to god Almighty or his countless, abundant and never ending blessings in completing this work. It is a proud privileged honor or us to express our hatful thanks and greatfulness to all the persons who backed us directly or indirectly through out o this research work as magnitude. Most importantly authors are thankful to patients and health care professionals

Conflict of interest: Yes

\section{References}

1. Curry PVL, Edwards AC, Sowton E: Relation between sites of ventricular tachycardia and underlying ventricular disease: im- plications for therapy. (abstr) Br Heart J 42: 237, 1979

2. Pedersen DH, Zipes DP, Foster PR, Troup PJ: Ventricular tachycardia and ventricular fibrillation in a young population. Circulation 60: 988, 1979.

3. Wei JY, Bulkley BH, Schaeffer AH, Greene HL, Reid PR: Mitral valve prolapse syndrome and recurrent ventricular tachyarrhythmias. Ann Intern Med 89: 6, 1978.

4. Pietras R, Bauerfeind RA, Lam W, Wyndham CRC, Rosen K: Right ventricular function and angiography in patients with right ventricular tachycardia without ischemic heart disease. (abstr) Am J Cardiol 45: 405, 1980.

5. Josephson ME, Horowitz LN, Farshidi A, Kastor JA: Recurrent sustained ventricular tachycardia. I. Mechanism. Circulation 57: 431, 1978.

6. Tenckhoff L, Stamm SJ, Beckwith JB: Sudden death in idio- pathic (congenital) right atrial enlargement. Circulation 40: 227, 1969.

7. Kohne DH, Wellens HJJ: Isolated aneurysmal enlargement of the right atrium. Ned T Geneesk 114: 1175, 1970.

8. Singh A, Katkov H, Zavoral JH, Sane SM, McLoed JD:Congenital aneurysms of the left ventricle. Am Heart J 99: 25, 1980.

9. Bakos ACP: The question of the function of the right ventric-ular myocardium, an experimental study. Circulation 1: 724, 1950.

10. Donald DE, Essex HE: Pressure studies after inactivation of the major portion ot the canine right ventricle. Am 3 Physiol 176: 155, 1954.

11. Forssman 0, Bjorkman G: Absence of the solid part of the right ventricular 
musculature. Acta Pathol Microbiol Scand (A) 80: 263, 1972.

12. Morand P, Lanfranchi J, Brehier J, Laine JL, Langevin JO, Raynaud R: Le syndrome de Uhl (ventricule droit papyrace). A propos d'une observation clinique avec controle hemo- dynamique, angiographique et isotopique. Semin Hop Paris 48: 571, 1972.

13. Dupont JC, Faton D, Perrin A: Le diagnostic clinique et hemodynamique de la maladie de Uhl chez l'adulte. A propos d'une observation. Lyon Med 231: 247, 1974.

14. Spurrell RAJ, Yates AK, Thornburn CW, Sowton GE, Deuchar DC: Surgical treatment of ventricular tachycardia after epicardial mapping studies. Br Heart J 37: 115, 1975.

15. Cherrier F, Floquet J, Cuilliere M, Neimann JL: Les dysplasies ventriculaires droites. A propos de 7 observations. Arch Mal Coeur 72: 766, 1979.

16. Segall HN: Parchment heart (Osler). Am Heart J 40: 948, 1950.

17. Castleman B, Towne VW: Case record of the Massachusetts General Hospital. N EngI J Med 246: 785, 1952.

18. Miller G, Lowenthal M, Krause S, Rosenbaum P: A saccular outpouching of the right ventricle in a child visualized by angiography. Am J Roentgenol 69: 69, 195.

19. Reeve R, MacDonald D: Partial absence of the right ventric-ular musculature: partial parchment heart. Am J Cardiol 14: 415, 1964.

20. Thiene, G., Nava, A., Corrado, D., Rossi, L. \& Pennelli, N. N. Engl. J. Med. 318, 129- 133 (1988).

21. Paul, M., Schulze-Bahr, E., Breithardt, G. \& Wichter, T.A. Z. Kardiol. 92, 128-136 (2003).

22. Gerull B, Heuser A, Wichter T, Paul M, Basson CT, McDermott DA, Lerman BB,
Markowitz SM, Ellinor PT, MacRae CA, Peters S, Grossmann KS, Drenckhahn J, Michely B, Sasse-Klaassen S, Birchmeier W, Dietz R, Breithardt G, Schulze-Bahr E, Thierfelder L. Mutations in the desmosomal protein plakophilin-2 are common in arrhythmogenic right ventricular cardiomyopathy. Nat Genet. 2004;36:1162-1164. 